\title{
老人福祉センターを利用する高齢者の 足トラブルの実態と関連要因の分析
}

\author{
狩 野太 郎, ${ }^{1}$ 小川妙子, ${ }^{1}$ 樋 口 友 紀 ${ }^{1}$ \\ 廣 瀬 規代美 ${ }^{1}$
}

\section{要 旨}

【背景・目的】本研究は, 老人福祉センターを利用する高齢者の足トラブルの実態と, 疾患及び足トラブル相 互の関連を分析し, 足トラブルが発生するメカニズムの検討を目的とした.【方法と対象】利用者 101 名を 対象に, 足部の観察と面接調查を行った. 足トラブルと疾患及び足トラブル相互の関連について $\chi^{2}$ 検定を用 いて分析した. 【結 果】足トラブルは足部皮膚乾燥 44.6\%, 角質肥厚 $40.6 \%$, 肥厚爪 $37.6 \%$ の順となって いた. 角質肥厚・足部皮膚乾燥・肥厚爪と高血圧に関連が見られた. 足卜ラブル相互の関連については, 角質 肥厚と肥厚爪, 胼胝と巻き爪に有意な関連が見られた。【結 語】高血圧と足トラブルの関連については不 明な部分が多いものの，末梢循環の低下や降圧利尿剂による影響が考元られ，足部皮膚乾燥や角質肥厚を有 する者の割合が高いことから, 重点的フットケア指導が有用と思われる. (Kitakanto Med J 2014；64： 335〜341)

キーワード : 高齢者, フットケア, 実態調查, 高血圧

\section{は じめに}

肥厚爪や外反母趾などの足トラブルは, 高齢者の転倒 や歩行能力低下の一因とされ, ${ }^{1-3}$ 介護予防の観点からも 高齢者に対するフットケアの重要性が指摘されてい る..$^{3-4}$ 厚生労働省は平成 15 年度新規事業として開始し た「介護予防・地域支元合い事業」の中で足指・爪のケ アに関する事業を中心事業の一つに位置づけ，地域にお ける足指・爪ケア教室等の開催や普及啓発パンフレット 等の配布により, 高齢者のフットケア向上を推進してい ๖. ${ }^{5}$

このような中で, 筆者らは地域で生活する高齢者の足 トラブルの実態とフットケアの実践状況を調查し, 肥厚 爪は足部の観察頻度が低い群に多くみられる一方, 深爪 は角質ケアや足部マッサージ, 意識的なフットケア実践 群に多く見られることを明らかにし，フットケアの基本 である観察の重要性と適切な爪切り方法等のフットケア 指導の必要性などについて報告した. ${ }^{6}$
本稿では, 地域で自立した生活をおくり，老人福祉セ ンターを利用する高齢者の足トラブルの実態と, 年齢, 性別, 現疾患および足トラブル相互の関連を分析し, 足 トラブルが発生するメカニズムの検討と今後重点指導を 考慮すべきリスクグループの検討を行ったので報告す る.

\section{対象と方法}

対 象: 北関東の地方都市にある $\mathrm{A}$ 老人福祉センター の利用者 101 名を対象とした. 同センターは市内に数カ 所ある老人福祉法に基づく老人福祉センターのひとつ で, 利用者は無料で入浴施設やマッサージ器扔よび娛楽 室などを利用でき，看護師による機能訓練や健康相談を 受けることもできる. 利用者は抢もに市内 4 つの経路を 週 3 回運行される無料巡回バスを利用して来場している が，近隣から徒歩や自転車抢よび自家用車で来場する者 もある. 同センターの利用者は, 毎週数回利用する常連 利用者のほか, 社交ダンスや手芸などの自主クラブへの

1 群馬県前橋市上沖町323-1 群馬県立県民健康科学大学看護学部 平成 26 年 8 月 26 日 受付

論文別刷請求先 $=371-0052$ 群馬県前橋市上沖町323-1 群馬県立県民健康科学大学看護学部 狩野太郎 


\begin{tabular}{|c|c|}
\hline & 基 \\
\hline 足部皮膚乾燥 & 足部の皮膚にうるおいがなく, カサつきや落屑がみられる状態を皮膚乾燥ありとした \\
\hline 角 質 肥 厚 & $\begin{array}{l}\text { 触診により足底接地面皮膚に著明な硬化を認め, 踵部のざらつきや亀裂・皮剝け, 白色〜黄色の色調変化 } \\
\text { などがみられるものを質肥厚ありとした }\end{array}$ \\
\hline 足 部 冷 感 & 触診により足部の冷感を認め, 日常的に足部の冷えを自覚していると回答した者を足部冷感ありとした \\
\hline 足 部 浮 腫 & 10 秒間の圧迫により足背に圧痕を認めた例を浮腫ありとした \\
\hline 外反母 趾 & 母趾中足趾節関節が腓骨側へ顕著に外反した, 外反母趾角がおおおむね $15^{\circ}$ 以上の状態を外反母趾とした \\
\hline 肥厚 爪 & 足趾の爪甲が著明に肥厚し, 第 1 趾の爪甲の厚さがおおむね $2 \mathrm{~mm}$ 以上の状態を肥厚爪とした \\
\hline
\end{tabular}

参加を主目的にした週 1 回程度の利用者も多い. 平成 20 年度の一日平均利用者は 233 名であった.

調査方法: 平成 21 年 3 月に 6 日間にわたってロビーに 調査ブースを設け, 来訪した高齢者に対して調査説明を 行い, 調査協力者が 100 名を超えるまで調査を行った.

研究への同意が得られた 65 歳以上の男女高齢者に対 し，以下 1)-5) の内容について質問紙を用いた面接聞き 取り調査と，5名の調査員による足部の観察と問診を実 施した。なお，調查時は 2 名の調查員がペアになって同 センターを訪問し, 足トラブルの評価に迷う場合は 2 名 で協議の上判定した。

1 ）基本的属性：性別, 年齢, 現疾患

2 ) 移動能力: 自立歩行または, 杖歩行等

3 ）フットケア習慣: 入浴頻度, 足部の保湿ケア, 足 部の運動, 足部のマッサージ

4 ) 転倒経験の有無 : 怪我の有無にかかわらず，過去 1 年間の転倒経験の有無と回数

5 ）足トラブルの有無：足トラブルに関する解説やカ ラー写真が多数掲載されている日本フットケア学 会編によるテキスト7-8 等を参考に, 表 1 に示した 基準を設け, 視触診や問診により評価

分析方法：足トラブルと対象の基本属性, 疾患等の関連 については $\chi^{2}$ 検定, 年齢や入浴頻度との関連は $\mathrm{t}$ 検定を 用いて分析した. なお, $2 \times 2$ 分割表では, イエーツの補正 による $\chi^{2}$ 值を求め, 有意確率については Fisher の Exact Testを用いた。

\section{用語 の定義}

「足トラブル」とは, 足趾や足背, 足底, 踵部の皮膚変 化，足趾や爪甲の変形など足部の問題状況を示す．足部 の問題状況には, 外反母趾や白癬など, 医師の診断に基 づく判断が必要な病変も含まれるが, 本研究では厳密な 規定はせず, 研究者の肉眼的観察と触診により判断可能 な足部の問題と定義し, 判断基準を設定した. なお, 本研 究では加齢に伴う足トラブルの観察に重点を置いたた め, 扁平足については扱わなかった.

\section{倫 理 的 配 慮}

対象者に対し, 研究目的と調査方法, 個人情報の保護, 自由意志による研究参加と協力中止の自由等についてロ 頭と書面により説明し, 研究同意書への署名により同意 を得た. なお, 本研究は所属大学の倫理委員会の承認を 得て実施した (群馬県立県民健康科学大学平成 20 年度 承認).

\section{結果}

\section{1. 対象者の概要}

調査開始直後より, 常連利用者を中心に多くの高齢者 が調査ブースを来訪し, 積極的な調查協力を得ることが できた. 調査ブース来訪者のうち, 約 10 名からは調査協 力が得られなかったが，大半は時間がないとの理由であ り，足をみられたくないとの理由から協力が得られな かったのは数名だった. 調査を終えた対象者が, 施設内 の休媳室で他の利用者に調査の紹介をしてくれたため, 調査期間中来場していた常連利用者の概ね 7-8 割から 調査協力が得られた.

対象者は, 男性 32 名 (31.7\%), 女性 69 名 (68.3\%) と, センター利用者の男女比を反映して女性が多く，年齢は 65 歳から 96 歳, 平均 76.4 (SD6.5) 歳となっていた. 対象 者の現疾患は, 高血圧が 28 名 $(27.7 \%)$ と最も多く, 糖尿 病 17 名 $(16.8 \%)$, 心疾患 14 名 $(13.9 \%)$, 脳血管疾患 11 名 $(10.9 \%)$, 骨関節疾患 10 名 $(9.9 \%)$ の順となっていた。 移動能力については完全に自立している者が 87 名 (86.1\%), 杖やシルバーカーを要する者が 14 名 (13.9\%) となっていた，過去 1 年間の転倒経験を有する者は 49 名 $(48.5 \%)$ にのぼり, 年間 3 回以上転倒を経験している 者が 14 名 (13.9\%) となっていた.

対象者の足トラブルについて表 2 に示した. 足部皮膚 乾燥が最も多く, 角質肥厚, 肥厚爪, 胼胝, 外反母趾など も多くみられた. 足部の血行状態の観察を目的に行った 触診では, 足部冷感が 41 名 (40.6\%) にみられたほか, 10 名 $(9.9 \%)$ に足背動脈の触知困難がみられた. なお, 肥厚 爪についてはほとんどが爪甲の白濁や黄色変化を伴う肥 厚性変形であり, 変形した爪甲がボロボロに崩れている 
など爪白癬によるものと思われる例が多かった，爪甲鉤

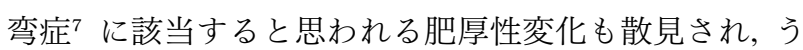
ち 1 名は数センチに達する鈎状に彎曲した爪甲を放置し ていたため, 早期の皮膚科への受診を勧めた

表 2 足トラブルの出現状況 人 $(\%)$

\begin{tabular}{ll}
\hline 足トラブル & \\
足部皮膚乾燥 & $45(44.6)$ \\
角質肥厚 & $41(40.6)$ \\
肥厚爪 & $38(37.6)$ \\
胼胝 & $22(21.8)$ \\
外反母趾 & $19(18.8)$ \\
足部浮腫 & $13(12.9)$ \\
巻き爪 & $13(12.9)$ \\
さじ状爪 & $10(9.9)$ \\
足部冷感 & $41(40.6)$ \\
足背動脈 & \\
触知不良 & $10(9.9)$ \\
\hline & \multicolumn{2}{c}{$\mathrm{n}=101$}
\end{tabular}

表 3 対象者のフットケア習慣

入浴頻度

毎日

4-6/週

2-3/週

無回答

足部の保湿ケア

毎日実施

時々実施

ほとんどしない

足部の運動

毎日実施

時々実施

ほとんどしない

足のマッサージ

毎日実施

時々実施

ほとんどしない

無回答

人 $(\%)$

$50(49.5)$

$13(12.9)$

$32(31.7)$

$6(5.9)$

$20(19.8)$

$33(32.7)$

$48(47.5)$

$44(43.6)$

$33(32.7)$

$24(23.8)$

$17(16.8)$

$20(19.8)$

$61(60.4)$

$3(3.0)$

$\mathrm{n}=101$

表 4 高血圧と関連がみられた足トラブル

人 $(\%)$

\begin{tabular}{|c|c|c|c|c|}
\hline & & \multicolumn{2}{|c|}{ 高血圧 } & \multirow{2}{*}{ 検定 } \\
\hline & & なし & あり & \\
\hline \multirow{2}{*}{ 角質肥厚 } & なし & $51(69.9)$ & $9(32.1)$ & \multirow[t]{2}{*}{$10.4^{* *}$} \\
\hline & あり & $22(30.1)$ & $19(67.9)$ & \\
\hline \multirow{2}{*}{ 肥厚爪 } & なし & $53(72.6)$ & $10(35.7)$ & \multirow[t]{2}{*}{$10.2^{* *}$} \\
\hline & あり & $20(27.4)$ & $18(64.3)$ & \\
\hline \multirow{2}{*}{ 足部皮膚乾燥 } & なし & $45(61.6)$ & $11(39.3)$ & \multirow[t]{2}{*}{$3.2^{*}$} \\
\hline & あり & $28(38.4)$ & $17(60.7)$ & \\
\hline
\end{tabular}

対象者のフットケア習慣を表 3 に示した. 毎日入浴し ている者が対象者の半数を占め, 足部の保湿ケアについ ては毎日〜時々実施が半数，ほとんどしない者も半数と なっていた．足関節以下の足部の運動を毎日〜時々行っ ている者が 7 割を超え，4割の者が足部のマッサージを 行っていた.

\section{2. 疾患と足トラブルの関連}

疾患と足トラブルの関連について $\chi^{2}$ 検定を行ったと ころ, 高血圧と角質肥厚, 肥厚爪, 足部皮膚乾燥の有無に 関連がみられ，高血圧を持つ者はこれらの足トラブルが 高頻度にみられた (表 4). 一方, 糖尿病や心疾患など, そ の他の疾患と足トラブルには関連がみられなかった．高 血圧と角質肥厚，足部皮膚乾燥，肥厚爪の関連探索のた め, 足背動脈触知, 足部冷感の有無との関連を分析した が有意ではなかった。さらに，角質肥厚，足部皮膚乾燥， 肥厚爪の有無と, 年齢・入浴頻度 (回/週) の関連につい て, $\mathrm{t}$ 検定を用いて分析したが有意でなかった。

\section{3. 性別と足トラブルの関連}

足トラブルと性別との関連について $\chi^{2}$ 検定を行った ところ, 足部浮腫がみられた 13 名の全員が女性であり 性差が認められた $\left(\chi^{2}=5.3, \mathrm{p}<0.01\right)$. 一方, 他の足卜ラ ブルについては，外反母趾が男性の $12.5 \%$ ，女性の $21.7 \%$ に見られたものの, 性別による出現頻度の差は有 意でなかった。

\section{4.フットケア習慣と足トラブル}

足トラブルと入浴頻度 (回／週) の関連について $\mathrm{t}$ 検 定を行ったところ，入浴頻度と足トラブルには関連はみ られなかった. 表 3 に示したフットケア習慣と足トラブ ルの関連について分析したところ，保湿ケアと足部皮膚 乾燥に関連がみられた。毎日保湿ケアを行っている群で は足部皮膚乾燥が $20.0 \%$ たたのに対し，「時々」「ほと んどしない」と回答した群では 50\%以上に皮膚乾燥がみ られた (表 5).

\section{5. 加齢と足トラブル}

足トラブルと年齢の関連について $\mathrm{t}$ 検定を用いて分析 を行った. 年齢と外反母趾の有無に関連がみられ, 外反 母趾がない群の平均年齢が 75.5 (SD5.7) 歳であったのに

表 5 足部の保湿ケアの頻度と足部の皮膚乾燥

\begin{tabular}{|c|c|c|c|c|c|}
\hline \multirow{2}{*}{ 表 5} & \multirow{2}{*}{ アの頻) } & & 部の保湿ク & & \multirow{2}{*}{ 人 $(\%)$} \\
\hline & & 毎日 & 時久 & ほとんどしない & \\
\hline \multirow{2}{*}{ 足部皮膚乾燥 } & なし & $16(80.0)$ & $16(48.5)$ & $24(50.0)$ & \multirow[t]{2}{*}{$6.1^{*}$} \\
\hline & あり & $4(20.0)$ & $17(51.5)$ & $24(50.0)$ & \\
\hline
\end{tabular}


対し, 外反母趾群は 80.3 (SD8.2) 歳と高くなっていた $(\mathrm{t}=3.0, \mathrm{p}<0.01)$. さらに, 対象者を 75 歳未満, 75-80 歳未 満, 80 歳以降の 3 群に分類して足トラブルとの関連を $\chi^{2}$ 検定により検討したところ, 前述の $\mathrm{t}$ 検定同様に外反 母趾との関連がみられ，80歳未満の 2 つの群では $10 \%$ 程度にみられた外反母趾の割合が 80 歳以降の群では 34.4\%にみられた (表 6). 一方, 他の足トラブルと年齢に つては, $\mathrm{t}$ 検定㧍よび年齢階級を 3 群に分けた $\chi^{2}$ 検定で も関連はみられなかった。

\section{6. 足トラブルの相互関係}

足トラブルの発症メカニズムの検討を目的に，足卜ラ ブル相互の関連について検討した. 肥厚爪と角質肥厚に 関連がみられ，角質肥厚がない群では肥厚爪の合併が 28.3\%であるのに対し, 角質肥厚群では $51.2 \%$ が肥厚爪 を合併していた (表 7). また, 外反母趾と胼胝については 関連がみられない一方, 胼胝と巻き爪には関連がみられ た (表 8).

\section{7. 足トラブルと移動能力および転倒リスク}

移動能力と足トラブルについても $\chi^{2}$ 検定を用いて検 討した。移動に杖等を必要とする群では足部浮腫が $42.9 \%$, 胼胝が $50.0 \%$ にみられるな゙, 自立群に比べて高 頻度にみられた (表 9).

足トラブルと転倒リスクについて検討するため, 過去 一年間の転倒経験の有無と足トラブルの関連を分析した ところ有意な関連はみられなかった。このため, 対象者 の半数近くが過去一年間の転倒経験を有することをふま え, 年間 2 回以上転倒した群と, 転倒経験 1 回以下の 2 群に分けて再度分析を行った。 この結果, 年間 2 回以上 の転倒経験者の割合は, 角質肥厚がない群で $11.7 \%$ あ゙あ るのに対し角質肥厚群では $31.7 \%$ ，胼胝がない群では 15.2\%であるのに対し胼胝群では $36.4 \%$ に達するなど, 足トラブルと転倒リスクに関連がみられた (表 10).

\section{考察}

本研究では, 調査ブースを訪れたほとんどの高齢者か ら調查協力が得られ，また常連利用者と思われる高齢者 の 7-8 割から協力が得られたことから， $\mathrm{A}$ 老人福祉セン ター利用者の実態を把握する上では十分なサンプリング ができた．対象者の疾患については，高血圧が $27.7 \%$ と なっていたが，同年代の高齢者の高血圧による通院者率 は, 人口千対 245-300 となっており, ${ }^{9}$ 本調査の結果とほ ぼ符合した。一方，16.8\%を示した糖尿病は，国民健康・ 栄養調査 ${ }^{10}$ の報告と符合して抢り，対象者の申告による 疾患は一定の信頼性があると判断できる.

本研究では，高血圧を有する者で角質肥厚，足部皮膚

\begin{tabular}{|c|c|c|c|c|}
\hline 表 6 & 歯 & & & 人 $(\%)$ \\
\hline & 74 歳未満 & 75-79 歳 & 80 歳以上 & 検定 \\
\hline なし & $41(89.1)$ & $20(87.0)$ & $21(65.6)$ & $7.5^{*}$ \\
\hline あり & $5(10.9)$ & $3(13.0)$ & $11(34.4)$ & \\
\hline
\end{tabular}

表7 足トラブル相互の関連 角質肥厚と肥厚爪 人 (\%)

\begin{tabular}{ccccc}
\hline & & \multicolumn{2}{c}{ 角質肥厚 } & なし 検定 \\
\hline \multirow{2}{*}{ 肥厚爪 } & なし & $43(71.7)$ & $20(48.8)$ & $4.5^{*}$ \\
& あり & $17(28.3)$ & $21(51.2)$ & \\
\hline & & $\chi^{2}$ 検定 & $* \mathrm{p}<0.05$ & $\mathrm{n}=101$
\end{tabular}

表 8 足トラブル相互の関連 人 $(\%)$

\begin{tabular}{|c|c|c|c|c|}
\hline & & \multicolumn{2}{|c|}{ 胼胝 } & \multirow{2}{*}{ 検定 } \\
\hline & & なし & あり & \\
\hline \multirow{2}{*}{ 巻き爪 } & なし & $72(81.8)$ & $16(18.2)$ & \multirow[t]{2}{*}{$3.7^{*}$} \\
\hline & あり & $7(53.8)$ & $6(46.2)$ & \\
\hline \multirow{2}{*}{ 外反母趾 } & なし & $65(79.3)$ & $17(20.7)$ & \multirow{2}{*}{ n.s. } \\
\hline & あり & $14(73.7)$ & $5(26.3)$ & \\
\hline
\end{tabular}

表 9 移動自立度と関連がみられた足トラブル人 (\%)

\begin{tabular}{ccccc}
\hline & & \multicolumn{3}{c}{ 移動 } \\
& & 要自助具 & 自立 & 検定 \\
\hline \multirow{2}{*}{ 足部浮腫 } & なし & $8(57.1)$ & $80(92.0)$ & $10.1^{* *}$ \\
\hdashline & あり & $6(42.9)$ & $7(8.0)$ & \\
\hdashline & なし & $7(50.0)$ & $72(82.8)$ & $5.8^{*}$ \\
\multirow{2}{*}{ 胼胝 } & あり & $7(50.0)$ & $15(17.2)$ & \\
\hline & $\chi^{2}$ 検定 & $* \mathrm{p}<0.05, * * \mathrm{p}<0.01$ & $\mathrm{n}=101$
\end{tabular}

表10 過去 1 年間の転倒頻度とおもな足トラブル 人 (\%)

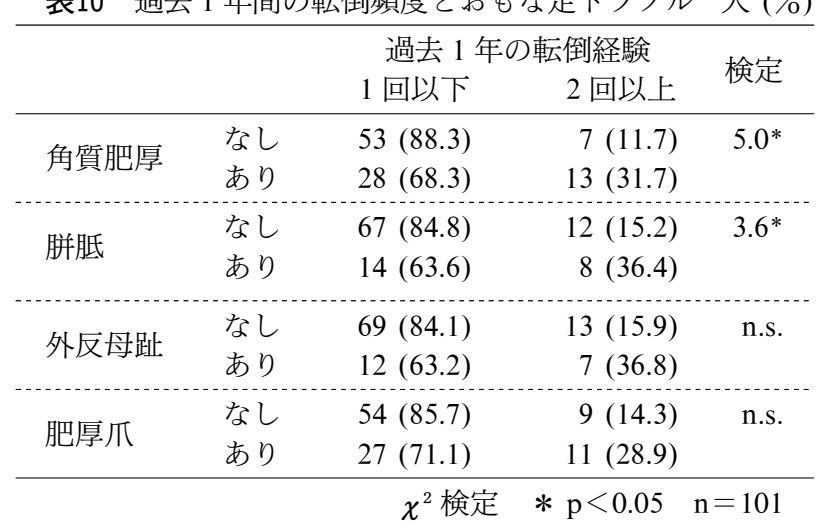

乾燥, 肥厚爪の割合が高くなっていた. 先行研究では糖 尿病や血液透析との関連 ${ }^{8}$ が報告される一方, 足トラブ ルに関連する単独の要因として高血圧は報告されておら ず, 本研究による新たな知見といえる.なお，これらの足 トラブルと，対象者の年齢や入浴頻度には関連は見られ ず，加齢や清潔習慣が交絡因子とは考えにくい状況で あった。

長期間におよぶ高血圧状態により, 四肢の末梢循環不 全が起こることが知られ, ${ }^{11}$ 本態性高血圧患者では健常 者に比べて寒冷負荷による皮膚温低下が大きく, 血漿) 
ルエピネフリンの上昇も大きいことが報告されている. ${ }^{12}$ これらのことから, 高血圧を有する者では, 下肢の未梢 循環の低下に伴い，皮膚や爪甲の再生や成長が阻害され， 古くなった角質や爪甲下角質が肥厚するというメカニズ ムが働いていると推測され, 表 7 に示した角質肥厚と肥 厚爪の関連性はこのメカニズムの仮説を支持するものと 考えられる.一方, 肥厚爪についてはその原因の多くは 爪白癬と考えられているが, ${ }^{13}$ 爪甲の成長・再生期間の延 長に加え末梢循環の低下による組織免疫力の低下が爪白 癬の悪化につながり, 白癬菌による爪甲下角質の増殖が 肥厚爪を生じていると考えられる. 足部皮膚乾燥につい ても皮膚の再生期間の延長が関与していると考えられる が，対象者が服用している降圧・利尿薬の影響も考えら れ, 今後の詳細な研究が待たれるところである.なお, 表 5 に示したとおり足部の保湿ケアを毎日行っている者で は足部皮膚乾燥がある者の割合が低くなっており，この 結果はセルフケアによる効果を示すものと考えられた.

地域在住高齢者 1 万人を対象に, 足トラブルと転倒経 験の関連を調べた調查 ${ }^{14}$ では, 「循環器系疾患 (高血圧・ 脳卒中・心臓など)」として高血圧に限定した分析ではな いものの, これらの治療を受けていると回答した群で 「足部皮膚の炎症・むくみ・変色」「爪の肥厚・変形」「足 指の血流障害・機能障害」の割合が高くなっており，高血 圧を有する者で肥厚爪の割合が高いという本研究の結果 と一致していた，一方，この調査では足部皮膚乾燥や角 質肥厚については調査項目に含まれていないため, 循環 器系疾患との関連は報告されていなかった．今回の研究 結果により，高血圧患者を糖尿病や腎不全患者などの八 イリスクグループに次ぐ「リスクグループ」としてとら え, 足部の観察や保湿, 足部の循環促進に向けた足趾や 足関節の運動指導など, 重点的フットケア指導の対象に 加える意義が示唆された. また, 健康高齢者を対象とし た基本的なフットケア教室の場面で, 高血圧と足トラブ ルに関する本研究の結果を紹介することで, 高血圧症を もつ参加者の学習意欲の向上に役立てられると考えられ る. なお，本研究では糖尿病と足トラブルには有意な関 連は見られなかったが, 糖尿病を有するものが 17 名と 少ないことによる検出力の不足と考えられる.

本研究では, 足部浮腫は女性のみにみられ男性にはみ られなかったが, 文献検索を試みても本邦における地域 在住の健康高齢者を対象とした下腿浮腫に関する先行研 究は見当たらなかった. 介護者と共に通院している高齢 者を対象とした調査では, 142 名中 55 名 (38.7\%) に下腿 浮腫が見られ，男女差は見られなかったと報告してい る. ${ }^{15}$ 一方，女性は男性に比べ手術や放射線治療などに続 発する二次性リンパ性浮腫の頻度が高いことが知られて おり, ${ }^{16}$ 加齢に伴う腎機能低下は女性で頻度が高く, 下腿
浮腫の一因となっている ${ }^{17}$ との指摘もある.このほか, 下 肢筋肉量の減少 ${ }^{17}$ や長時間座位 ${ }^{18}$ や長時間立位 ${ }^{17}$ などの ライフ・スタイルが下腿浮腫の出現に影響しているため, 今回の調查ではこれらの影響が男女差として顕在化した ものと推測される.

対象者の年齢と足トラブルの出現頻度を分析したとこ ろ, 加齢に伴って外反母趾を有する者の割合が高くなっ ていた．加齢に伴う外反母趾の増加は米国で行われてい る大規模なコホート研究である Framingham Foot Study でも同様の結果が報告されており, ${ }^{19}$ 先細の靴や八イ ヒールを履く習慣などにより若い頃に亜脱臼した MTP 関節が筋バランスの崩れによって徐々に変形が増悪する とされている. ${ }^{20}$

足トラブル相互の関連についての分析では, 肥厚爪と 角質肥厚, 胼胝と巻き爪に関連が見られた. 肥厚爪と角 質肥厚の関連については, 前述のように高血圧に伴う末 梢循環不全や皮膚の乾燥が影響していると考えられる。 胼胝と巻き爪の合併は臨床的にも報告されており, ${ }^{21}$ 足 に合わない靴を履くことによる圧迫が共通の原因として 指摘されている. 8,22

同様に外反母趾と胼胝の合併も知られているが, 8,22 今 回の調査では有意な関連が見られなかった．この点につ いては, 本調査はケース数が 101 名であるため, 検出力 の不足を考慮する必要がある.

一方，足トラブルと移動能力の関連に関する分析では, 自立歩行群にくらべて杖歩行等を要する群で足部浮腫や 胼胝の割合が高くなっていた．横断的調査のため, 関連 の時間的関係は十分考察できないが, 移動能力の低下に より下肢の運動量が減少することが足部浮腫の一因とな り, 一方, 足部浮腫や胼胝が歩行に支障を来すことで, 杖 等が必要になっているとも考えられる.いずれにしても 杖歩行等, 歩行能力の低下が見られる場合は「リスクグ ループ」として, 重点的フットケア指導の対象に加える 必要があるだろう。

足トラブルと転倒の関連については, 国内外の先行研 究で報告されているが, ${ }^{1-3,23}$ 本研究では足トラブルと過 去 1 年間の転倒経験には関連がみられず, 先行研究とは 異なる結果となった. 対象の約半数が過去 1 年間の転倒 経験を有していたことから，年間 2 回以上転倒した群と， 転倒経験 1 回以下の 2 群に分けて再度分析を行ったとこ ろ, 角質肥厚と胼胝で関連が見られた. 312 名の高齢者を 対象としたKaren ら,23 176 名の高齢者を対象とした Menz $ら^{1}$ のそれぞれ 12ケ月にわたる縦断的研究では, 外 反母趾と転倒の関連が報告されているが, 本研究では有 意ではなかった.この点についても，本調査はケース数 が 101 名であるため, 検出力の不足を考慮する必要があ る. 
高歯者のフットケアについて検討する際には, 足トラ ブルと転倒リスクの関係は最も大きな関心事の一つとい えるが, 前述の通り 200-300 名を対象とした複数の縦断 的研究によってその関連性が確認されている.今回の 我々の調查は 101 名の地域健康高齢者を対象とした小規 模な横断的研究であるが, 得られた結果はこれらの適切 にデザインされた縦断的研究や多くの先行研究と概ね矛 盾のないものであった. 今後, 地域高齢者を対象とした フットケア教室などにおいて本研究結果を提示・活用す ることで, 参加者がより身近な問題として足トラブルを 認識するのに役立つものと思われる.

\section{謝 辞}

本研究にご協力いただいた $\mathrm{A}$ 老人福祉センター利用 者の皆様, 並びに職員の皆様に心より感謝申し上げます.

本研究は平成 20 年度群馬県立県民健康科学大学共同 研究費により行った。

\section{文献}

1. Menz HB, Morris ME, Lord SR. Foot and ankle risk factors for falls in older people : a prospective study. J Gerontol A Biol Sci Med Sci 2006 ; 61(8) : 866-870.

2. Hiramatsu T, Izumi K, Shogenji M. Relationship between foot problems and foot care, physical function and falls in community-dwelling elderly. J Nurs Inve $2011 ; 9(2): 25-32$

3. 原田和弘, 岡浩一朗, 柴田 愛ら. 地域在住高齢者におけ る足部に関する問題と転倒経験・転倒不安との関連. 日本 公衆衛生雑誌 $2010 ； 57(8) ： 612-623$.

4. 姫野稔子, 小野ミツ. 在宅高齢者の介護予防に向けたフッ トケアの効果の検討. 日本看護研究学会雑誌 2010 ; 33(1) : $111-120$

5. 第 5 章 第 2 節健康で豊かな高齢社会のために. 厚生労 働白書 2004 ：204

http://www.mhlw.go.jp/wp/hakusyo/kousei/04/dl/2-5. pdf

6. 樋口友紀, 小川妙子, 狩野太郎ら. 地域で生活する高歯者 の足トラブルとフットケアニーズに関する研究. 群馬県 立県民健康科学大学紀要 $2011 ; 6: 55-65$.

7. 日本フットケア学会編. はじめよう!フットケア. 東京 : 日本看護協会出版会, 2006.

8. 日本フットケア学会編. フットケア 基礎的知識から専門 的技術まで. 東京 : 医学書院, 2006.

9. 大臣官房統計情報部人口動態・保健社会統計課世帯統計
室. 平成 25 年国民生活基礎調査の概況

http://www.mhlw.go.jp/toukei/saikin/hw/k-tyosa/ktyosa13/index.html

10. 厚生労働省健康局総務課生活習慣病対策室. 平成 18 年国 民健康・栄養調查の概要 厚生労働省, 2006: 30. http://www.mhlw.go.jp/houdou/2008/04/dl/h0430-2c. pdf

11. 勝田洋輔. 高血圧と合併症-新たな治療展開. 日本医師会 雑誌 $2005 ; 134(3): 41-44$.

12. 有馬 健, 久代登志男, 梶原長雄. 本態性高血圧症におけ る皮膚循環動態と交感神経機能の特徵について. 循環器 科 $1989 ; 26(2): 195-200$.

13. 西田壽代. 爪のアセスメント 色, 厚み, 乾燥, 形, 切り方 / 伸び方に要注意. コミュニティケア 2005；7(12)：7173.

14. 原田和弘, 岡浩一朗, 柴田 愛ら. 地域在住高齢者におけ る足部に関する問題と転倒経験・転倒不安との関連. 日本 公衆衛生雑誌 $2010 ； 57(8) ： 612-623$.

15. 深沢雷太, 小山俊一, 金高秀和ら. CGA スクリーニング テストでみられた外来通院患者の下肢浮腫とその関連因 子. 日本老年医学会雑誌 $2013 ; 50(3) ： 384-391$.

16. 高山 豊.【循環器疾患における性差医療】末梢血管疾患 診療に扔ける性差. 成人病と生活習慣病 2009；39(10)： 1141-1144.

17. 長澤康行, 今井圓裕. 高齢者ケアのガイドライン(17) 浮 腫. ジェロントロジーニューホライズン $2006 ; 18$ : 247-252.

18. 北村有香, 白井みどり, 佐々木八千代ら. 施設入所高齢者 の車椅子座位姿勢における下肢周径の経時的変化. 老年 看護学 $2012 ； 17(1)$ : 91-97.

19. Alyssa B D, Virginia AC, Yvonne MG, et al. Characteristics associated with hallux valgus in a population-based study of older adults: The Framingham Foot Study. DOI : $10.1002 /$ acr. 22391

20. 大関 覚.【高齢者におけるロコモティブシンドローム】 運動器の機能解剖とロコモティブシンドローム ロコモ ティブシンドロームに扔ける足・足関節疾患の診断と治 療. Geriatric Med 2012；50：1057-1060.

21. 倉片長門, 鈴木啓之. 陥入爪の成因の検討ならびに陷入爪 に対する VHO 法の効果について. 日本皮膚科学会雑誌 2004; 114(2) : 173-178.

22. 塩之谷香. 靴で治す足のトラブルと超弾性ワイヤーによ る巻き爪治療の実際. 日本保険医学会誌 $2004 ; 102(3)$ : 245-252.

23. Karen JM, Bridget JM, Stephen RL, et al. Toe weakness and deformity increase the risk of falls in older people. Clin Biomechanics 2009; 24(10) : 787-791. 


\title{
Investigation of the Actual Status of Foot Problems in Elderly People Visiting Welfare Centers for Elderly Citizens and Analysis of Related Factors
}

\author{
Taro Kano, ${ }^{1}$ Taeko Ogawa, ${ }^{1} \quad$ Yuki Higuchi ${ }^{1}$ \\ and Kiyomi Hirose ${ }^{1}$ \\ 1 Department of Nursing, Gunma Prefectural College of Health Sciences, 323-1 Kamioki- \\ machi, Maebashi, Gunma 371-0052, Japan
}

\begin{abstract}
Background and Purpose : The purpose of this study was to investigate the actual status of foot problems in elderly people visiting welfare centers for elderly citizens and analyze the relationships between diseases and foot problems, as well as the mutual relationships among foot problems, to clarify the mechanisms of development of foot problems. Subjects and Methods : We conducted a survey of the actual status of foot problems by observing the feet and conducting interviews of 101 visitors. The relationships between diseases and foot problems, as well as the mutual relationships among foot problems were analyzed by the $\chi^{2}$ test. Results : In regard to foot problems, xerosis cutis of the foot was seen in $44.6 \%$ of the subjects, followed in frequency by skin thickening in $40.6 \%$ and nail thickening in $37.6 \%$ of the subjects. All of xerosis cutis, skin thickening and nail thickening were related to the presence of hypertension. As to the mutual relationships among foot problems, there was a significant association between skin thickening and nail thickening, as well as between callus and ingrowing toenails. Conclusion: Although much remains unknown about the association between hypertension and foot problems, reduction in the peripheral circulatory function and use of antihypertensive diuretic drugs may have an influence. Considering the high rates of xerosis cutis and skin thickening encountered in the subjects, we consider that it would be useful to focus on foot care education for elderly people.

(Kitakanto Med J 2014; 64:335 341)
\end{abstract}

Key words : elderly people, foot care, actual condition survey, hypertension 